\title{
Genetic diversity in South African Nguni cattle ecotypes based on microsatellite markers
}

\author{
Yandisiwe Sanarana $^{1,2}$ - Carina Visser ${ }^{1}$ Lydia Bosman ${ }^{1} \cdot$ \\ Khathutshelo Nephawe $^{3} \cdot$ Azwihangwisi Maiwashe $^{2} \cdot$ Este van Marle-Köster $^{1 \#}$ \\ " Corresponding author. Email: evm.koster@up.ac.za \\ ${ }^{1}$ Department of Animal and Wildlife Sciences, University of Pretoria, Private Bag X20, Hatfield 0028, \\ South Africa \\ ${ }^{2}$ Agricultural Research Council, Private Bag X2, Irene, 0062, South Africa \\ ${ }^{3}$ Department of Animal Science, Tshwane University of Technology, Private Bag X680, Pretoria 0001, \\ South Africa
}

\section{Abstract}

The Nguni cattle breed is a landrace breed adapted to different ecological regions of South Africa. A number of ecotypes are recognised based on phenotype within the breed, but it is not known if they are genetically distinct. In this study molecular characterization was performed on Makhathini (MAK), Pedi (PED), Shangaan (SHA) and Venda (VEN) Nguni cattle ecotypes. Two Nguni cattle populations, not kept as separate ecotypes, from University of Fort Hare (UFH) and Agricultural Research Council Loskop South farm (LOS) were also included. Genotypic data was generated for 189 unrelated Nguni cattle selected based on pedigree records using 22 microsatellite markers. The expected heterozygosity values varied from $69 \%$ (UFH) to $72 \%$ PED with a mean number of alleles ranging from 6.0 to 6.9 . The $\mathrm{F}_{\mathrm{ST}}$ estimate demonstrated that $4.8 \%$ of the total genetic variation was due to the genetic differentiation between the populations and 92.2\% accounted for differences within the populations. The genetic distances and structure analysis revealed the closest relationship between MAK, PEDI and SHA ecotypes, followed by SHA and VEN. The UFH population clustered with the MAK ecotype, indicating that they are more genetically similar, while the LOS cattle grouped as a distinct cluster. Results suggest that the genetic differentiation between the PED and SHA ecotypes is low and can be regarded as one ecotype based on 
limited genetic differences. The results of this study can be applied as a point of reference for further genetic studies towards conservation of Nguni cattle ecotypes.

Keywords: Population structure $\cdot$ Conservation $\cdot$ Ecotypes $\cdot$ microsatellites

\section{Introduction}

The Nguni cattle breed is a multi-purpose breed that plays an important role in both commercial and communal farming systems in South Africa (Ramsay et al. 2000). It is recognised as an important animal genetic resource possessing valuable adaptive traits resulting in a breed that can survive and reproduce efficiently in marginal production areas (Mapiye et al. 2007; Matjuda et al. 2014). Nguni cattle are not only able to tolerate harsh environmental conditions but also have natural immunity to tick-borne diseases and parasites that could limit livestock production (Marufu et al. 2011; 2014).

The Nguni is considered as a sub-type of Sanga (Bos taurus Africanus) that originated from the imported Arabian Peninsula bulls (Hanotte et al. 2000; Decker et al. 2014). Mitochondrial DNA analysis confirmed the origin of Nguni cattle from humped Bos indicus and the humpless Bos taurus (Horsburgh et al. 2013). The early development of the breed was shaped by evolutionary forces such as migration, genetic drift and selection. It was introduced to the eastern and southern areas of Africa by the nomadic people who migrated from North Africa (Mwai et al. 2015). According to archaeological evidence the breed dates back 2000 years ago in South Africa and was introduced via three migration routes (Schoeman 1989).

Over time, different ethnic groups settled in different geographic regions of South Africa and selected cattle based on phenotypes such as horn shape and size, body conformation and coat colour patterns (Oosthuizen 1996). Distinctive Nguni cattle ecotypes developed that were 
adapted to different environmental regions (Bester et al. 2003). The South African Nguni cattle ecotypes recognised include Bartlow, Makhathini, Pedi, Shangaan and Venda. These ecotypes are linked to the geographic areas where the specific ethnic groups keeping the breed settled and relate to their traditional historic existence and foundation. The majority of Nguni cattle in South Africa consist of large numbers of registered females kept in stud and commercial herds without differentiation into the known ecotypes. Specific ecotypes are kept in small numbers by a number of stud breeders. Selection of the Nguni breed has been primarily based on phenotypic traits and to a lesser extent performance recording.

Molecular data is a useful tool to investigate the genetic diversity and differentiation among species and breeds. Microsatellite markers have been widely used to evaluate the genetic diversity of indigenous cattle breeds (FAO, 2011). Genetic diversity has been investigated in a number of developing countries on breeds such as the Ankole longhorn (Ndumu et al. 2008; Kugonza et al. 2011) and Afrikaner cattle breeds (Pienaar et al. 2014) as well as a number of indigenous cattle breeds in Mozambique (Bessa et al. 2009), Cuba (Acosta et al. 2013), Cameroon (Ngono-Ema et al. 2014) and India (Sharma et al. 2015).

The Pedi and Makhathini Nguni cattle ecotypes of South Africa have been listed by the Food and Agricultural Organisation (FAO) as endangered breeds (Scherf 2000). Therefore, immediate interventions are required to conserve the limited number of ecotypes existing. To our knowledge, no genetic studies have been conducted to study the population structure and diversity of South African Nguni ecotypes. The aim of this study was to assess the genetic diversity and population structure of South African Nguni cattle ecotypes for genetic management and conservation using a set of 22 microsatellite markers. 


\section{Materials and Methods}

\section{Sample collection and preparation}

The use of animals for this study was performed according to and with approval by the Animal Ethic Committee (AEC) of the University of Pretoria (EC111-13). Hundred and eighty nine unrelated Nguni cattle were selected based upon pedigree records from South African stud farmers, Mara Research Station, Agricultural Research Council - Animal Production Institute (ARC-API) in Loskop and the University of Fort Hare Honeydale farm (UFH) as indicated in Fig. 1.

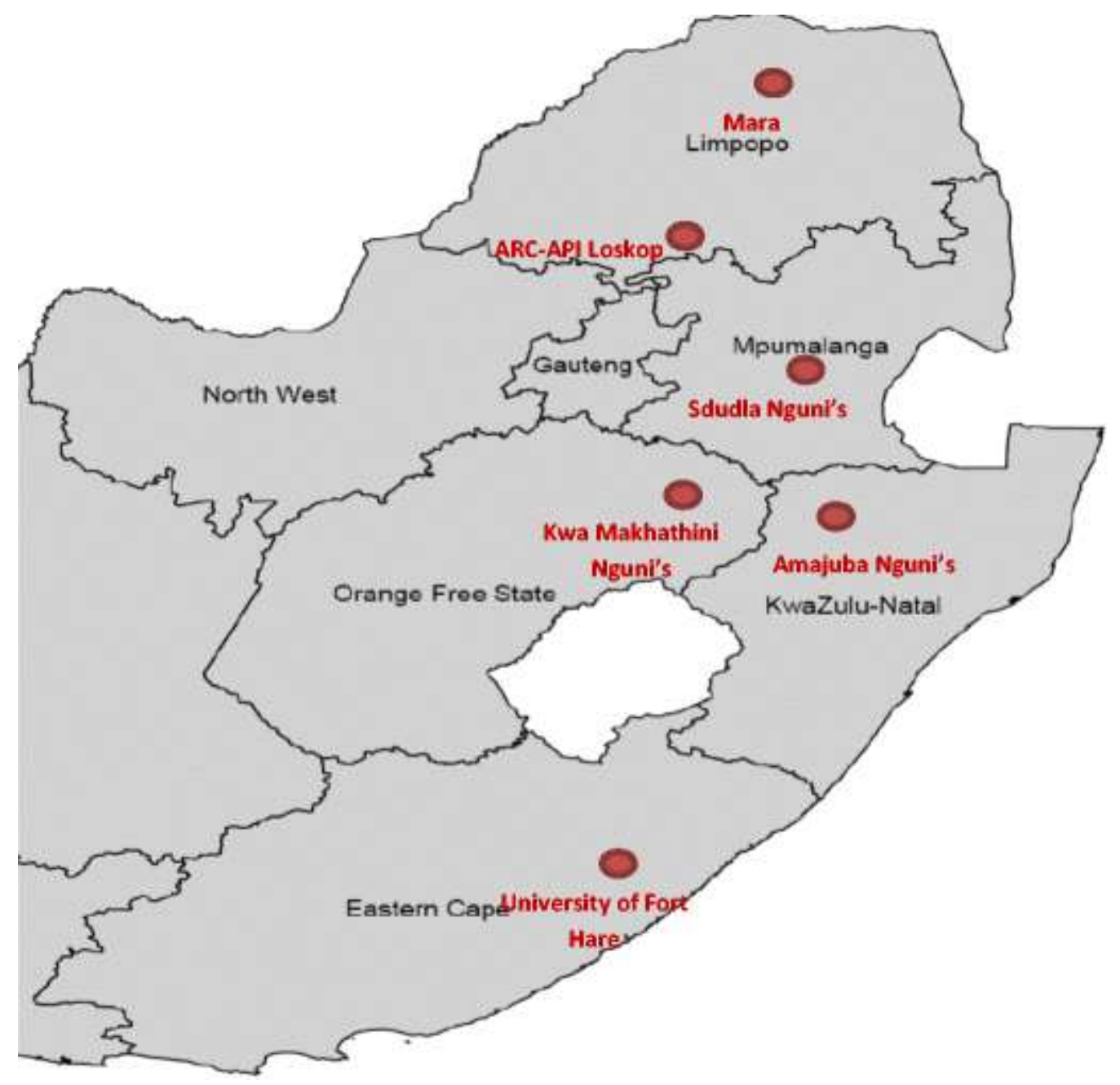

Fig.1 Distribution of Nguni cattle ecotypes included in the study 
The UFH and LOS populations were not defined previously as separate ecotypes and therefore in this study referred to as unknown ecotypes. Tail hair samples were collected from the animals at ARC-API and UFH and kept separately in envelopes to avoid contamination. The samples were grouped accordingly into four Nguni cattle ecotypes in Fig.2 as Makhathini (MAK), Pedi (PED), Shangaan (SHA) and Venda (VEN) ecotypes, and LOS and UFH as unknown ecotypes. The genomic (gDNA) was extracted from the hair samples using Phenol chloroform protocol (Sambrook et al. 1989) in the Animal Genetics laboratory at ARC-API. Blood samples were collected from the animals at the Mara research station. For each animal $5 \mathrm{ml}$ blood was collected in an EDTA tube from the jugular vein and kept at 4 degrees Celsius until extraction could be performed. DNA was extracted from the whole blood samples using Roche High Pure PCR Template Preparation kit (Roche IN USA).The concentration of the gDNA was measured using spectrophotometer (Nanodrop 2000) and purity verified by the 260/280 absorbance ratio (Thermo Fisher Scientific Inc. Waltham MA USA).
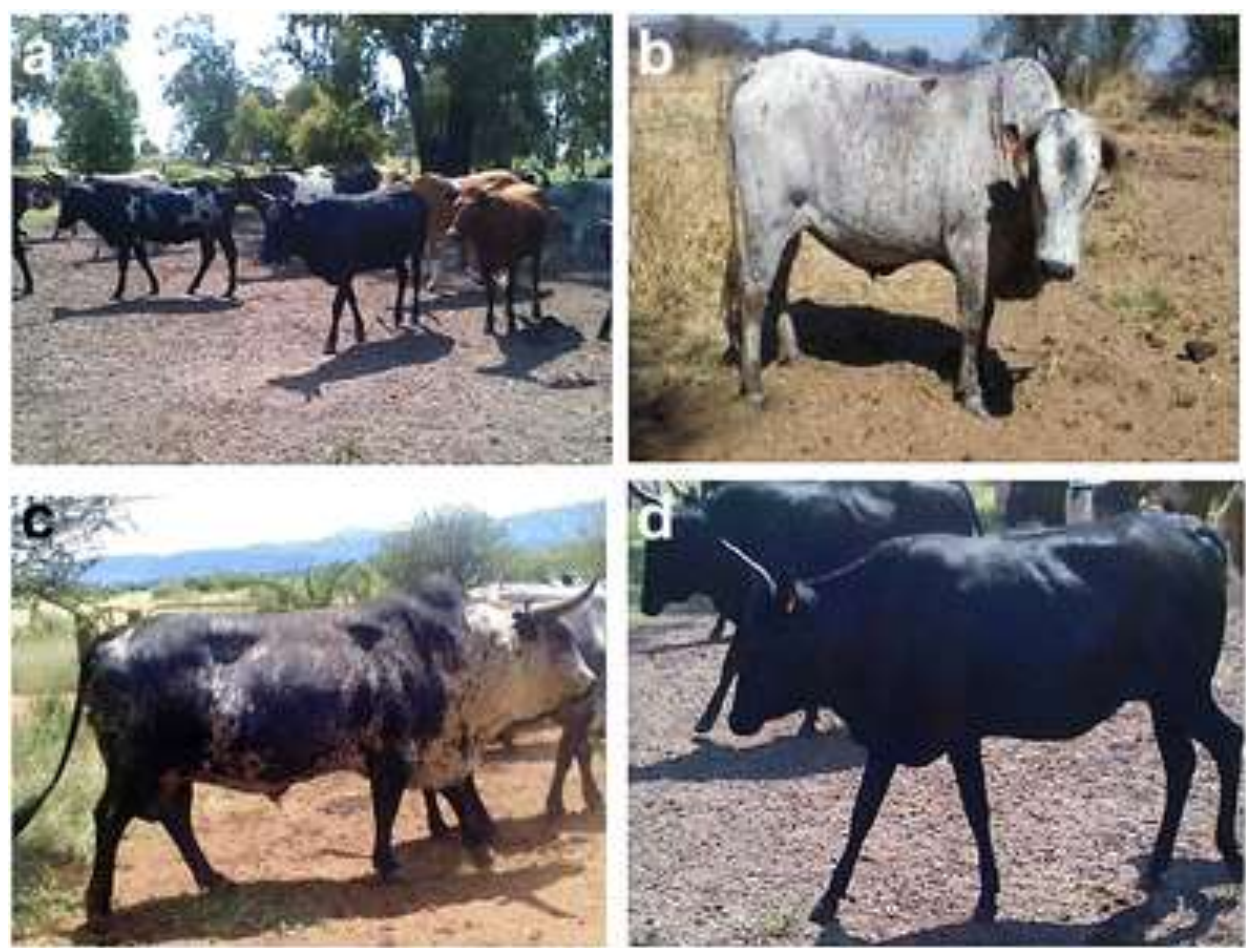

Fig. 2 South African Nguni cattle ecotypes studied 
Polymerase chain reaction (PCR) and genotyping

Twenty two microsatellite markers selected from the International Society for Animal Genetics (ISAG) bovine panel list of markers (HEL1, INRA63, ETH185, TGLA126, HEL5, ILSTS006, INRA37, ETH152, INRA23, CSRM60, CSSM66, TGLA227, TGLA122, ETH10, INRA35, ETH225, ETH3, TGLA53, BM1818, BM2113, BM1824 and SPS115) were used to amplify the gDNA. These markers are endorsed for estimating genetic diversity parameters by ISAG and FAO advisory board (FAO 2011).

The PCR and genotyping were performed in the Animal Breeding and Genetics laboratory of the University of Pretoria. A $15 \mu \mathrm{l}$ reaction was prepared with molecular water; $10 \mathrm{x}$ buffer optimized with $50 \mathrm{mM} \mathrm{MgCl}_{2}$ and $100 \mathrm{mM}$ deoxynucleotides triphosphates; 5U Bioline MyTaq DNA polymerase ${ }^{\circledR}$ (Bioline USA Inc.); $0.3 \mu \mathrm{l}$ of $10 \mathrm{~mol} / \mu \mathrm{l}$ primers (Applied Biosystems Foster city CA USA) and $5 \mu 1$ of 50-100 ng of gDNA. The amplification of the DNA samples was performed using Perkin Elmer Gene Amp PCR System ${ }^{\circledR} 9700$ Thermal cycler (Applied Biosystems Foster city CA USA) programmed to run as follows: $94^{\circ} \mathrm{C}$ for 10 minutes; 33 cycles of denaturation at $94^{\circ} \mathrm{C}$ for 45 seconds, specific marker annealing temperature for 90 seconds and replication at $72^{\circ} \mathrm{C}$ for 60 seconds, followed by a final extension at $72^{\circ} \mathrm{C}$ with time depended on marker and held at $4{ }^{\circ} \mathrm{C}$. After amplification, the PCR products were quantified using 3\% agarose gel stained with ethidium bromide and visualised under UV trans-illuminator. The amplified products were separated using the capillary electrophoresis ABI Prism 3130 Genetic Analyzer (Applied Biosystems Foster city CA USA) at Forestry and Agricultural Biotechnology Institute (FABI) department of the University of Pretoria. The data was imported to GeneMarker $1.95^{\mathrm{TM}}$ software (Applied Biosystems CA USA) to determine allele fragment sizes. 


\section{Statistical analysis}

Excel Microsatellite Toolkit (Park 2001) was used to estimate the basic population genetic descriptive statistics including heterozygosity values $\left(\mathrm{H}_{\mathrm{O}}\right)$ and $\left(\mathrm{H}_{\mathrm{E}}\right)$, total number of alleles, mean number of alleles (MNA) and private alleles. Arlequin version 3.1 (Excoffier et al. 2005) was used to perform the analyses of molecular variance (AMOVA) to determine genetic differences between the populations. The genetic relationship among Nguni cattle populations was determined according to Nei's standards (Nei 1987) using POPGen (Raymond and Rousset 1995). The genetic population structure analysis of Nguni cattle ecotypes was assessed using Bayesian admixture procedure implemented in STRUCTURE 2.3.4 (Pritchard et al. 2000) to infer the most likely number of clusters. The analysis was performed with a burn-in length of 100,000 followed by 500,000 MCMC (Markov Chain Monte Carlo) assuming that the dataset could be presented by $K$ separate clusters $(K=2$ to 12) with five iterations for each run. Likewise, the population analysis was performed for the Nguni cattle ecotypes including the UFH and LOS populations. The most probable number of populations was determined following the recommendation of Evanno et al. (2005). Different values of the number $(\mathrm{K})$ of priori defined clusters were compared and used to calculate the $\operatorname{Ln} \operatorname{Pr}(\mathrm{X} \mid \mathrm{K})$.

\section{Results}

Twenty two microsatellite markers were used to study the genetic diversity of six South African Nguni cattle populations. A total number of 199 were alleles detected across the 22 microsatellite markers with an overall mean of nine. High gene diversity was found across the six populations with an average of $70 \%$ heterozygosity and 6.47 alleles per locus, as shown in Table 1. A total of eighteen distinct private alleles were found, shared between the 
MAK (4), UFH (4), LOS (4), PED (3) and VEN (3). No private alleles were found in the SHA population.

Table 1 Descriptive statistics of six Nguni cattle populations

\begin{tabular}{lcccccc}
\hline Population & $\begin{array}{c}\text { Sample } \\
\text { size }\end{array}$ & $\begin{array}{c}\text { Loci } \\
\text { typed }\end{array}$ & $\begin{array}{c}\text { Expected } \\
\text { Hz } \pm \text { SD }\end{array}$ & $\begin{array}{c}\text { Observed } \\
\text { Hz } \pm \text { SD }\end{array}$ & $\begin{array}{c}\text { Number } \\
\text { Alleles } \pm \text { SD }\end{array}$ & $\begin{array}{c}\text { Private } \\
\text { Alleles }\end{array}$ \\
\hline PED & 32 & 22 & $0.717 \pm 0.030$ & $0.689 \pm 0.010$ & $6.82 \pm 2.20$ & 3 \\
SHA & 30 & 22 & $0.688 \pm 0.030$ & $0.642 \pm 0.010$ & $6.27 \pm 1.70$ & 0 \\
VEN & 31 & 22 & $0.701 \pm 0.020$ & $0.682 \pm 0.010$ & $6.32 \pm 1.90$ & 3 \\
MAK & 32 & 22 & $0.702 \pm 0.030$ & $0.667 \pm 0.010$ & $6.70 \pm 2.40$ & 4 \\
UFH & 32 & 22 & $0.687 \pm 0.030$ & $0.696 \pm 0.010$ & $6.68 \pm 2.40$ & 4 \\
LOS & 32 & 22 & $0.708 \pm 0.020$ & $0.789 \pm 0.010$ & $6.00 \pm 1.80$ & 4 \\
Mean & & & $\mathbf{0 . 7 0 1}$ & $\mathbf{0 . 6 9 4}$ & $\mathbf{6 . 4 7}$ & \\
\hline
\end{tabular}

Results presented in Table 2 indicated that $4.8 \%$ of the genetic variation was due to differences among populations and $95.2 \%$ was due to difference among individuals within populations.

Table 2 Analyses of molecular variance of six Nguni cattle populations

\begin{tabular}{lcccc}
\hline $\begin{array}{l}\text { Source of } \\
\text { variation }\end{array}$ & $\begin{array}{c}\text { Sum of } \\
\text { squares }\end{array}$ & $\begin{array}{c}\text { Variance } \\
\text { components }\end{array}$ & $\begin{array}{c}\text { Percentage of } \\
\text { variation }\end{array}$ & P-value \\
\hline $\begin{array}{l}\text { Between } \\
\text { populations }\end{array}$ & 155.678 & 0.39204 & 4.81702 & 0.001 \\
$\begin{array}{l}\text { Within } \\
\text { populations }\end{array}$ & 2786.65 & 7.74652 & 95.1829 & 0.001 \\
\hline Totals & 2942.33 & 8.13856 & & \\
\hline
\end{tabular}

Genetic distances between the ecotypes indicated relatively close relationships among all the ecotypes with the shortest distance between MAK and UFH.

Table 3 Nei's Genetic Distance $\left(D_{A}\right)$ of six Nguni cattle populations analyzed

\begin{tabular}{lllllll}
\hline & PED & SHA & VEN & MAK & UFH & LOS \\
\hline PED & $* * * * *$ & & & & & \\
SHA & 0.132 & $* * * * *$ & & & & \\
VEN & 0.171 & 0.127 & $* * * * *$ & & & \\
MAK & 0.126 & 0.148 & 0.153 & $* * * * *$ & & \\
UFH & 0.129 & 0.150 & 0.150 & 0.112 & $* * * * *$ & \\
LOS & 0.210 & 0.223 & 0.209 & 0.203 & 0.169 & $* * * * *$ \\
\hline
\end{tabular}


Structure analysis results indicated that the most likely number of populations are four $(K=$ 4) where the highest proportion of animals were allocated to the MAK ecotype followed by the VEN, PED and SHA ecotypes as indicated in Table 4 and illustrated in Figure 2.

Table 4 Proportion of four Nguni cattle ecotypes in each of the four clusters $(K=4)$

\begin{tabular}{lcccc}
\hline Populations & \multicolumn{4}{c}{ Inferred clusters } \\
\cline { 2 - 5 } & $\mathbf{1}$ & $\mathbf{2}$ & $\mathbf{3}$ & $\mathbf{4}$ \\
PED & $\mathbf{0 . 6 6 8}$ & 0.080 & 0.038 & 0.214 \\
SHA & 0.137 & $\mathbf{0 . 5 5 3}$ & 0.188 & 0.122 \\
VEN & 0.023 & 0.133 & $\mathbf{0 . 7 5 1}$ & 0.093 \\
MAK & 0.028 & 0.084 & 0.043 & $\mathbf{0 . 8 5 0}$ \\
\hline
\end{tabular}

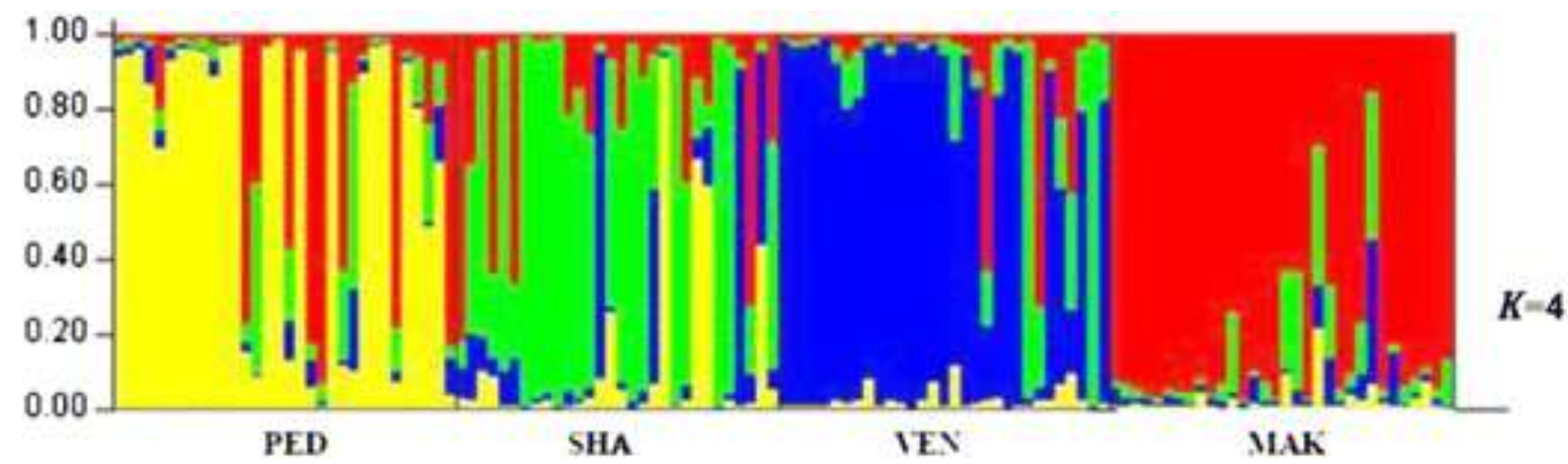

Fig. 3 Cluster assignment of 125 animals representing four South African Nguni cattle ecotypes at $\mathrm{K}=4$

The structure analyses including the UFH and LOS populations confirmed the previous clustering with SHA having only $46 \%$ of the animals allocated to this ecotype. $80 \%$ of the LOS grouped together while the UFH animals clustered with MAK (Table 5).

Table 5 Proportion of analyzed six Nguni cattle populations in each of the five clusters $(K=5)$

\begin{tabular}{lccccc}
\hline Populations & \multicolumn{5}{c}{ Inferred clusters } \\
\cline { 2 - 6 } & $\mathbf{1}$ & $\mathbf{2}$ & $\mathbf{3}$ & $\mathbf{4}$ & $\mathbf{5}$ \\
PED & $\mathbf{0 . 6 4 0}$ & 0.104 & 0.041 & 0.125 & 0.089 \\
SHA & 0.139 & $\mathbf{0 . 4 6 0}$ & 0.254 & 0.121 & 0.026 \\
VEN & 0.026 & 0.116 & $\mathbf{0 . 7 3 7}$ & 0.099 & 0.022 \\
MAK & 0.065 & 0.171 & 0.077 & $\mathbf{0 . 5 9 4}$ & 0.092 \\
UFH & 0.087 & 0.081 & 0.042 & $\mathbf{0 . 6 7 0}$ & 0.120 \\
LOS & 0.033 & 0.024 & 0.043 & 0.100 & $\mathbf{0 . 8 0 0}$ \\
\hline
\end{tabular}


In Figure 3 the apparent introgression between the SHA and PED as well as between the MAK and UFH populations are clearly visible.

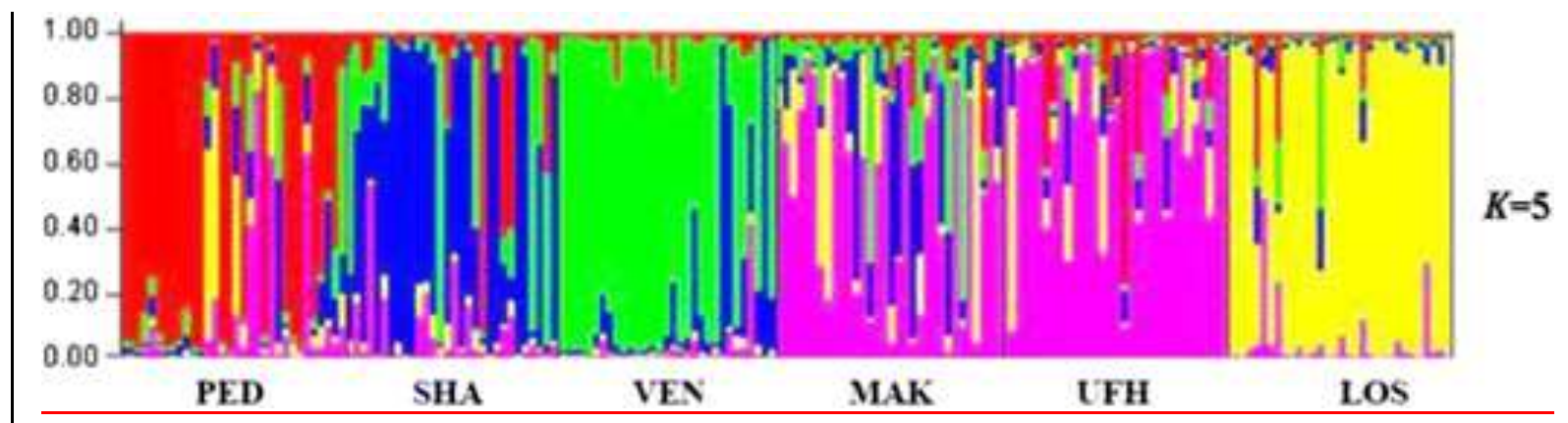

Fig. 4 Cluster assignment of 189 animals representing six Nguni cattle populations at $K=5$

\section{Discussion}

Nguni cattle are one of the largest indigenous cattle breeds in South Africa contributing to beef production in commercial and communal farming systems. Due to their origin and association to different geographical areas in South Africa, the ecotypes have been named accordingly (Oosthuizen 1996). Although the ecotypes tend to have specific phenotypes with regard to colour and body and or head conformation, genetic differentiation has not been confirmed. Studies to date has confirmed adaptability traits (Marufu et al. 2011, 2014) of the Nguni and identified genomic regions underlying tick resistance (Mapholi et al. 2015). In this study the focus was on the genetic diversity and population structure of the known and unknown ecotypes based on microsatellite markers.

All the markers were polymorphic and a total number of 199 alleles was observed across the populations with a mean number of nine. Private alleles were observed in each ecotype except in the SHA ecotype that shared alleles with all ecotypes. The absence of private alleles in SHA ecotype is probably due to migration and gene flow from other the other ecotypes over many generations and farmers selecting on performance and not only colour patterns or 
morphological traits (Nguni Cattle Breeders Society 2008). Private alleles could be useful for genetic identification of ecotypes. Private alleles are often observed in diversity studies on indigenous livestock (Ngono Ema et al. 2014) and can be used as a tool for measurement of genetic distinctiveness of a population (Szpiech and Rosenburg 2011).

Relatively high gene diversity values were observed among the six Nguni cattle populations studied. These values were higher compared to the gene diversity values reported in South African Afrikaner cattle populations (57\%) by Pienaar et al. (2014). The heterozygosity values observed in the current study were comparable to the values reported in indigenous cattle from Vietnam (Pham et al. 2013), Cameroon (Ngono Ema et al. 2014) and in India (Sharma et al. 2015). High gene diversity levels are normally associated with long-term natural selection for adaptation and the historic admixture of different populations (Ojango et al. 2011).

Moderate genetic differentiation was indicated by a $\mathrm{F}_{\mathrm{ST}}$ value of $4.8 \%$ between Nguni cattle populations and $92.8 \%$ within the Nguni cattle populations. Comparable figures were obtained among Mozambique cattle breeds by Bessa et al. (2009). Higher $\mathrm{F}_{\mathrm{ST}}$ levels were however reported in cattle breeds for Cameroon indigenous breeds (0.061) (Ngono-Ema et al. 2014), Ankole Longhorn cattle (0.090) (Ndumu et al. 2008) and Indian cattle breeds (0.133) (Sharma et al. 2015) respectively. The relatively close genetic relationships among the Nguni cattle ecotypes and populations were confirmed by the unbiased Nei's genetic distance pairwise matrix estimates.

The population structure analyses revealed clear admixture among the Nguni cattle ecotypes. The MAK ecotypes tend to have a clear presence in all the ecotype clusters. Phenotypically, the MAK shares coat colour patterns with most of the other ecotypes and can only be distinguished from other ecotypes by a short "V" shaped head and the small body size (Nguni 
Cattle Breeders Society 2008). The results indicate that UFH population consists primarily of the MAK ecotype. This is in line with the history of the UFH population primarily from KwaZulu Natal cattle herds, where the MAK ecotype originated (Somoro 2009). LOS clustered as a separate population; this population was subjected to selection based only on production performance, not colour or other phenotypic traits related to the ecotypes and this clearly has resulted in genetic distinctiveness. The genetic differences among the ecotypes observed are in agreement with phenotypic characteristics such as coat colour patterns, horn shapes and body frames that are analogous with Nguni cattle ecotypes described by the Nguni Breed Society (Nguni Cattle Breeders Society 2008).

Although the VEN and SHA ecotypes originate from regions in close proximity to each and admixture could be expected between the two ecotypes, it was observed that they clustered separately. This is mostly likely due to the geographical isolation imposed by the mountain ranges resulting in more uniform populations. Studies on local chickens indicated the Lebowa-Venda chickens being distant from other local chicken lines in the same geographical area due to selection on certain morphological characteristics and their geographical isolation in this region (van Marle-Köster et al. 2008).

This study indicates that although there is moderate to high genetic diversity within the Nguni population as a whole, the genetic differentiation between ecotypes was not high. Despite the phenotypic differences in ecotypes for specific colour variations and horn shape, these ecotypes show genetic relatedness and admixture. The Nguni is widely used in commercial livestock production due to its adaptive traits and as one of the most popular indigenous breeds have the potential to grow in population numbers and consequently also be subjected to selection for improved production. 
Vigilant consideration is required with regard to decisions for maintaining these ecotypes as distinct populations based on phenotype and genotype as well as the focus on maintenance of genetic diversity in the total Nguni population. The study could serve as a point of departure for future genetic studies on the conservation and utilization of these Nguni ecotypes in South Africa.

\section{Conclusion}

The results obtained in this study indicated that the Nguni ecotypes in South Africa have been affected by gene flow that resulted into moderate to low genetic differentiation among populations. There is also a clear indication of admixture among the ecotypes with clear separation where a Nguni population was subjected to selection. As the Nguni is an important indigenous breed with application in commercial and communal systems, it is important that further studies will consider the wider application of the breed with regard to adaptive and performance traits.

\section{Acknowledgements}

The authors are grateful and would like to acknowledge the funding from the Limpopo Department of Agriculture and Agricultural Research Council - Animal Production Institute (ARC-API). We are indebted to the Nguni Cattle Breeders Society and ARC Nguni project on tick resistance for donating samples to our project.

\section{Statement of Animal rights}


Use of the animals was granted an approval by the Animal Ethic Committee (AEC) under the University of Pretoria (EC111-13).

\section{Conflict of Interest Statement}

The authors declare no conflict of interest.

\section{References}

Acosta, A.C., Uffo, O., Sanz, A., Ronda, R., Osta, R., Rodellar, C., Martin - Burriel, I., Zaragoza, P., 2013. Genetic diversity and differentiation of five Cuban cattle breeds using 30 microsatellite loci. Journal of Animal Breeding and Genetics, 130, 79-86.

Bester, J., Matjuda, L.E., Rust, J M. and Fourie, H.J., 2003. Nguni: a case study. In: Vilakati et al. (eds) 2003. Community-based management of animal genetic resources. Rome: FAO.

Bessa, I., Pinheiro, I., Matola, M. and Dzama, K., 2009. Genetic diversity and relationship among indigenous Mozambican cattle breeds. South African Journal of Animal Science 39, 61-72.

Decker, J. E., McKay, S. D., Rolf, M. M., Kim, J., Molina Alcalá, A., Sonstegard, T. S., Hanotte, O., Götherström, A., Seabury, C. M., Praharani, L., Babar, M.E., Correia de Almeida Regitano, L., Yildiz, M. A., Heaton, M.P., Liu, W.S., Lei, C.Z., Reecy, J.M., Saif-Ur-Rehman, M., Schnabel, R.D. and Taylor, J.F., 2014. Worldwide patterns of ancestry, divergence, and admixture in domesticated cattle. PLoS Genetics 10(3):e1004254.

Evanno, G., Regnaut, S. and Goudet, J., 2005. Detecting the number of clusters of individuals using software STRUCTURE: a simulation study. Journal of Molecular Ecology, 14, 2611-2620.

Excoffier L., Laval G. and Schneider S., 2005. Arlequin version 3.1: an integrated software package for population genetics data analysis. Evolution Bioinformatics Journal, 1, 47-50.

FAO, 2011. Molecular genetic characterization of animal genetic resources. FAO Animal Production and Health Guidelines, No.9. Rome, Italy.

Hanotte, O., Okomo, M., Tawah, C.L., Bradley, D. G., Okomo, M., Verjee, Y. and Rege, J.E.O., 2000. Geographical distribution and frequency of a taurine Bos taurus and an indicine Bos indicus Y specific allele amongst sub-Saharan African cattle breeds. 
Molecular ecology Journal, 9, 387-396

Horsburgh, K.A., Prost, S., Gosling, A., Stanton, J.A., Rand, C. and Matisoo-Smith, E.A., 2013. The Genetic Diversity of the Nguni Breed of African Cattle (Bos spp.): Complete Mitochondrial Genomes of Haplogroup T1. PLoS ONE (8) 8, 1-6.

Kugonza, D.R., Jianlin, H., Nabasirye, M., Mpairwe, D., Kiwuwa, G.H., Okeyo, A.M., Hanotte, O., 2011. Genetic diversity and differentiation of Ankole cattle populations in Uganda inferred from microsatellite data. Journal Livestock Science, 135, 140-147.

Mapholi, N.O., Maiwashe, A., Nedambale, L., MacNeil, M.D. \& Dzama, K., 2015. Genomic analysis of tick resistance in South African Nguni cattle. Proceedings of the $48^{\text {th }}$ South African Society for Animal Science Congress, Empangeni, 21-23 July.

Mapiye, C., Chimonyo, M., Muchenje, V., Dzama, K., Marufu, M.C. and Raats, J.G., 2007. Potential for value-addition of Nguni cattle products in the communal areas of South Africa. African Journal of Agriculture (2) 10, 488-495.

Marufu, M.C., Qokweni, L., Chimonyo, M., Dzama K., 2011. Relationships between tick counts and coat characteristics in Nguni and Bonsmara cattle reared on semi-arid rangelands in South Africa. Ticks Tick-Borne Diseases Journal, 2, 172-177.

Marufu, M.C., Dzama, K. and Chimonyo, M., 2014. Cellular responses to Rhipicephalus microplus infestations in pre-sensitised cattle with differing phenotypes of infestation. Experimental and Applied Acarology Journal, 62, 241-252. DOI 10.1007/s10493013-9723-5.

Matjuda, L.E., MacNeil, M.D., Maiwashe, A., Leesberg, V.R. \& Malatje, M., 2014. Index-inretrospect and breeding objectives characterizing genetic improvement programmes for South African Nguni cattle/ South African Journal of Animal Science, 44 (2), 161 172.

Mwai, O., Hanotte, O., Knon, Y.J. and Cho, S., 2015. African Indigenous Cattle: Unique Genetic Resources in Rapid Changing World. Asian Australas Journal of Animal Science (28) 7, 911-921.

Ndumu, D. B., Baumung, R., Hanotte, O., Wurzinger, M., Okeyo, M. A., Jianlin, H., Kibogo, H. and Solkner, J., 2008. Genetic and morphological characterization of the Ankole Longhorn cattle in the African Great Lakes region. Genetic Selection Evolution, 40, $467-490$.

Nei, M., 1987. Molecular evolutionary genetics. New York, Columbia University Press.

Ngono Ema, P.J., Manjeli, Y., Meutchieyie, F., Keambou, C., Wanjala, B., Desta, A.F., Ommeh, S., Skilton, R., Djikeng, A., 2014. Genetic diversity of four Cameroon indigenous cattle using microsatellite markers. Journal of Livestock Science, 5, 9-17.

Nguni Cattle Breeders Society, 2008. The breed from the past for the future. PO Box 506, Bloemfontein, 9300.

Ojango, J.M., Mpofu, N., Marshall, K. and Andersson-Eklund, L., 2011. Quantitative methods to improve the understanding and utilization of animal genetic resources. In: 
Ojango, J.M., Malmfors, B. and Okeyo, A.M (eds), Animal Genetics Training Resources. International Livestock Research Institute, Nairobi, Kenya and Swedish University of Agricultural Science, Uppsala, Sweden

Oosthuizen, M.P., 1996. A descriptive study of the Sanga-Nguni cattle of the Zulu people with special reference to colour-pattern Terminology and Naming-practice. PhD Thesis. University of Natal, Department of Zulu, South Africa.

Park, S.D.E., 2001. Trypanotolerance in West African and the population genetic effects of selection. PhD Thesis. University of Dublin, Dublin, Ireland.

Pham, L.D., Do, D.N., Binh, N.T., Nam, L.Q., Ba, N.V., Thuy, T.T.T., Hoan, T.X., Cuong, V.C., Kadarmideen, H.N., 2013. Assessment of genetic diversity and population structure of Vietnamese indigenous cattle populations by microsatellites. Journal of Livestock Science, 155, 17-22.

Pienaar, L., Grobler, J.P., Neser, F.W.C., Scholtz, M.M., Swart, H. Ehlers, K. and Marx, M., 2014. Genetic diversity in selected stud and commercial herds of the Afrikaner cattle breed. South African Journal of Animal Science, 44, 80-84.

Pritchard, J.K., Stephens M. and Donnelly P., 2000. Inference of population structure using multilocus genotype data. Journal of Genetics, 155, 945-959.

Ramsay, K., Harris, L. and Kotze, A., 2000. Landrace Breeds: South Africa's Indigenous and Locally Developed Farm Animals. Farm Animal Conservation Trust, Pretoria.

Raymond M. and Rousset F., 1995. Genepop 1.2 - population-genetics software for exact tests and ecumenisms. Journal of Heredity, 86, 248-249.

Sambrook, J., Fritsch, E.F. and Maniati S.T., 1989. Molecular cloning: a laboratory Manual, Vol. 3. Cold Spring Harbor Laboratory Press, Cold Spring Harbor, New York.

Sharma, R., Kishore, A., Mukesh, M., Ahlawat, S., Maitra, A., Pandey, A.K. and Tantia, M.S., 2015. Genetic diversity and relationship of Indian cattle inferred from microsatellite and mitochondrial DNA markers. Bio Med Central Genetics, 16, 73-84.

Scherf, B.D., 2000. World Watch List for domestic animal diversity ( $3^{\text {rd }}$ edition). Food and Agricultural Organization of the United Nations, Rome, Italy.

Schoeman, S.J., 1989. Recent research into the production potential of indigenous cattle with specific reference to Sanga. South African Journal of Animal Science, 19, 55 - 61.

Somoro, L.M., 2009. The design, implementation and effects of the Nguni project in the Eastern Cape Province of South Africa. M-Thesis. University of Fort Hare, Faculty of Science and Agriculture, Department of Agricultural Economics and Extension, School of Agriculture and Agribusiness, South Africa.

Szpiech, Z. and Rosenburg, N.A., 2011. On the size distribution of private microsatellite alleles. Theoretical population Biology Journal 80, 100-113.

van Marle-Köster, E., Hefer, C.A., Nel, L.H. and Groenen, M.A.M., 2008. Genetic diversity and population structure of locally adapted South African chicken lines: Implications for conservation. South African Journal of Animal Science (38) 4, 271-281. 